American Journal of Agricultural and Biological Sciences 3 (4): 656-660, 2008

ISSN 1557-4989

(C) 2008 Science Publications

\title{
Evaluating Agro-Climatologically Variables to Identify Suitable Areas for Rapeseed in Different Dates of Sowing by GIS approach
}

\author{
${ }^{1}$ A. Ghasemi Pirbalouti and ${ }^{2}$ A. Golparvar \\ ${ }^{1}$ Department of Medicinal Plants and Plant Products, \\ Islamic Azad University of Shahrekord Branch, P.O. Box: 166, Shahrekord, Iran \\ ${ }^{2}$ Department of Agronomy and Plants Breeding, \\ Islamic Azad University of Khorasgan Branch, Isfahan, Iran
}

\begin{abstract}
The study carried out in tow provinces (Isfahan and Chaharmahal va Bakhtyiari), central and southwest, Iran. The study area covers approximately $37659 \mathrm{Km}^{2}$ of total area. This area is located between latitude $30^{\circ} 42^{\prime} \mathrm{N}$ and $33^{\circ} 37^{\prime} \mathrm{N}$ and between longitude $49^{\circ} 56^{\prime} \mathrm{W}$ and $51^{\circ} 57^{\prime} \mathrm{W}$. The climate variables taken into account were maximum and minimum daily average temperature, Growth Degree Day (GDD) between four dates of sowing to physiological maturity and four dates sowing to freezing start day (rosette), monthly precipitation, monthly relative humidity (March to May) and number of freezing days. Climate variables and DEM data layers were prepared and suitability classes were determined, using simple limitation (SLA) purposed by modified of FAO method, were matched against specific winter oilseed rape (Brassica napus L.) requirements derived from agricultural experiments and literature review. The results indicated that the main limited factors are GDD from sowing to physiological maturity and sowing to freezing start day. The overlay maps for climate variables and DEM suitability evaluation using SLA identified 11.2\% (sowing date: 20 August to 5 September), $12.5 \%$ (sowing date: 6 September to 20 September), $0.4 \%$ (sowing date: 21 September to 5 October) and $0.06 \%$ (sowing date: 6 October to 20 October) of the surface area land have suitable in study area.
\end{abstract}

Key words: Rapeseed, climate, GIS, suitable area, sowing date

\section{INTRODUCTION}

The increase in the burgeoning population of the world and the shortage of the resources to meet the requirements for food has increased the need for oil and protein sources. The plants are the most important sources of oil and protein for humans and animals nutrition $^{[4]}$. The world area cultivated by Brassica species has been increased rapidly during the last decade due to the intensive work to improve the oil and meal quality of Brassica species $^{[7]}$.

Winter oilseed rape (Brassica napus L.) the most important of oilseeds and has potential to become an alternate oilseed crop in Central, Iran. Rapeseed (Brassica napus L.) is widely grown as an oilseed crop in the world, but has a very limited acreage in Iran. In general, some of the provinces in Iran have a suitable climate for oilseeds. The most of land of Isfahan and Chaharmahal va Bakhtyiari have a cool and short growing season, where the oilseed crops usually perform poorly except rapeseed. Rapeseed is a new and promising oilseed crop for this region. In these regions the information on sowing dates of rapeseed is an important step for the forecast of the rapeseed yield $^{[10,11]}$.

The potential of land for agricultural use is determined by an evaluation of the climate, soil and topographical environmental components and the understanding of local biophysical restraints ${ }^{[3,10,11]}$. This evaluation is an essential step for the development of agriculture. It is necessary to assess the land suitability for rapeseed cultivation in the area by integrating various kinds of information with spatial analysis technique. The result of land suitability assessment presented in the form of map and report are meaningful to a local user ${ }^{[5]}$. Geographic Information System (GIS) has the ability to perform numerous tasks utilizing both spatial and attribute data. One of the most useful features of GIS is the ability to overlay different layers or maps ${ }^{[1]}$.

Subjects of study, GIS can be effectively applied to handle such kinds of work and to complete study

Corresponding Author: A. Ghasemi Pirbalouti, Department of Medicinal Plants and Plant Products, Islamic Azad University of Shahrekord Branch, P.O. Box: 166, Shahrekord, Iran 
objectives, these are to construct the geographical databases of land suitability for rapeseed (Brassica napus L.), to assess land suitability for rapeseed using GIS in different sowing dates and to select the possible lands for new rapeseed sowing in Isfahan and Chaharmahal va Bakhtyiari provinces, Iran.

\section{MATERIALS AND METHODS}

The most important areas for rapeseed (Brassica napus L.) production in Iran are the Isfahan and Chahar Mahal va Bakhtyiari provinces. The study area covers approximately $37659.9 \mathrm{Km}^{2}$ of total area of Isfahan and Chaharmahal va Bakhtyiari provinces (Fig. 1). This area is located between latitude $30^{\circ} 42^{\prime} \mathrm{N}$ and $33^{\circ} 37^{\prime} \mathrm{N}$ and between longitude $49^{\circ} 56^{\prime} \mathrm{W}$ and $51^{\circ} 57^{\prime} \mathrm{W}$ (Central and West Iran). The natural vegetation is rangeland and oak forest. Most of the area is used for rain-fed agriculture. The rapeseed crop was chosen in this investigation because has recently been exploited to boost cultivation areas in Isfahan and Chaharmahal va Bakhtyiari provinces.

Meteorological information was obtained from variation weather stations located within the study area and the surrounding zone. The number of years registered at the weather stations ranged from 15-20. Average values for each variable per 10-day calendar period were calculated. The minimum and maximum temperature maps were adjusted by a thermal gradient. This regional thermal gradient was generated by a regression model that took into account the elevation and temperature of weather stations located in Central and West Iran. The variables taken into account were maximum and minimum daily average temperature, monthly precipitation, monthly relative humidity (March to May) and number of freezing days. In order calculation of growth degree day (GDD) between four sowing dates: 20 August to 5 September (date 1), 6 September to 20 September (date 2), 6 October to 20 October (date 3) and 6 October to 20 October (date 4) to physiological maturity and four sowing dates to freezing start day (rosette) used Eq. $1^{[6]}$ :

$$
\mathrm{GDD}=\left[\left(\mathrm{T}_{\max }+\mathrm{T}_{\min }\right) / 2\right]-\mathrm{T}_{\text {base }}
$$

$\mathrm{T}_{\max }$ : Maximum daily temperature average

$\mathrm{T}_{\min }$ : Minimum daily temperature average

$\mathrm{T}_{\text {base }}: 5^{\circ} \mathrm{C}$ a temperature below which no development occurs for a given winter rapeseed

The slope and elevation information were obtained from the Digital Elevation Model (DEM) using two well-known GIS software packages ILWIS ver-academic ${ }_{3.0}^{[1,14]}$. This array was geo-referenced using a metric

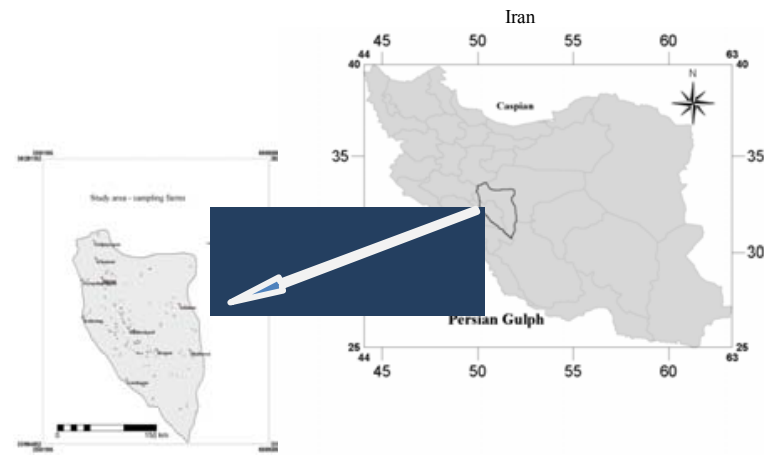

Fig. 1: Location of the study site, Chaharmahal va Bakhtyari and Isfahan Provinces, Iran

UTM coordinate system and the geometric correction was carried out in the GIS ILWIS.

The rapeseed growth parameters were obtained through the different illustration. These parameters were complied into one database for analysis (Table 1). The rapeseed suitability classifications used were based of the food and agriculture organization ${ }^{[8]}$.

\section{RESULTS AND DISCUSSION}

The polygon map for elevation indicated that $31.7 \%\left(11938 \mathrm{~km}^{2}\right), 48 \%\left(18090 \mathrm{~km}^{2}\right)$ and $19.8 \%$ $\left(7467 \mathrm{~km}^{2}\right)$ of study area is placed in moderate $(1500-$ 2000 masl), marginally suitable (2000-2500 masl) and not suitable $(2500$ masl $<)$ categories, respectively (Fig. 2a). Only $0.44 \%\left(164 \mathrm{~km}^{2}\right)$ of the study area was high suitable (1000-1500 masl) category. Slope, an important element of landform, plays an important role where mechanization and irrigation is concerned ${ }^{[9]}$. The result of polygon map of slope in study lands identified that $14588.9 \mathrm{~km}^{2}(38.8 \%)$ and $23071 \mathrm{~km}^{2}(61.3 \%)$ of land have currently suitable (slope $0-2.5 \%$ ) and unsuitable (slope $>7.5 \%$ ) for irrigated rapeseed crop production in central and west Iran, respectively (Fig. 2b).

Numerous research studies for different climates have shown that sowing date influences the growth, seed yield and quality of rapeseed ${ }^{[11,13,15]}$. This study results indicated that the main limited factors are GDD from sowing to physiological maturity and sowing to freezing start day. The results of suitability evaluation of overlay maps DEM with GDD in four sowing dates to physiological maturity and four sowing dates to freezing start day (rosette) using SLA shows in Table 2 and 3.

Since early frosts are common and cool conditions prevail in the late October, sowing date can play a major role in determining the suitable regions with 
Am. J. Agri. \& Biol. Sci., 3 (4): 656-660, 2008

Table 1: Rapeseed oil crop growth parameters (Brassica napus L.)

\begin{tabular}{lllll}
\hline Variables & $\mathrm{S}_{1}$ & $\mathrm{~S}_{2}$ & $\mathrm{~S}_{3}$ & $\mathrm{~N}$ \\
\hline Climatic & $400-500 \mathrm{~mm}$ & $300-400 \mathrm{~mm}$ & $250-300 \mathrm{~mm}$ & $<250 \mathrm{~mm}$ \\
$\begin{array}{l}\text { Annual rainfall } \\
\text { Optimal temperature }\end{array}$ & $17-20^{\circ} \mathrm{C}$ & $20-25^{\circ} \mathrm{C}$ & $25-30^{\circ} \mathrm{C}$ & $>30^{\circ} \mathrm{C}$ \\
& & & $10-15^{\circ} \mathrm{C}$ & $<10^{\circ} \mathrm{C}$ \\
$\begin{array}{l}\text { Growing degree } \\
\text { Topography }\end{array}$ & $2000-2500 \mathrm{dd}$ & $1500-2000 \mathrm{dd}$ & $>2500 \mathrm{dd}$ & $1500 \mathrm{dd}>$ \\
$\begin{array}{l}\text { Elevation } \\
\text { Slope }\end{array}$ & $1000-1500 \mathrm{~m}$ & & & $2000-2500 \mathrm{~m}<$ \\
\hline
\end{tabular}

Table 2: Suitability evaluation of overlay maps of DEM with GDD in four sowing dates to physiological maturity using SLA by GIS

\begin{tabular}{|c|c|c|c|c|c|c|c|c|c|}
\hline \multirow[b]{2}{*}{ Class } & \multirow[b]{2}{*}{ GDD } & \multicolumn{2}{|l|}{ Date 1} & \multicolumn{2}{|l|}{ Date 2} & \multicolumn{2}{|l|}{ Date 3} & \multicolumn{2}{|l|}{ Date 4} \\
\hline & & $\begin{array}{l}\text { Area } \\
\text { land (\%) }\end{array}$ & $\begin{array}{l}\text { Area land } \\
\left(\mathrm{Km}^{2}\right)\end{array}$ & $\begin{array}{l}\text { Area } \\
\text { land (\%) }\end{array}$ & $\begin{array}{l}\text { Area land } \\
\left(\mathrm{Km}^{2}\right)\end{array}$ & $\begin{array}{l}\text { Area } \\
\text { land (\%) }\end{array}$ & $\begin{array}{l}\text { Area land } \\
\left(\mathrm{Km}^{2}\right)\end{array}$ & $\begin{array}{l}\text { Area } \\
\text { land (\%) }\end{array}$ & $\begin{array}{l}\text { Area land } \\
\left(\mathrm{Km}^{2}\right)\end{array}$ \\
\hline$\overline{S_{1}}$ & $2000-2500$ & 27.2 & 10234.7 & 32 & 12053 & 19.6 & 7393 & 5.4 & 2036.2 \\
\hline \multirow[t]{2}{*}{$\mathrm{S}_{2}$} & $1500-2000$ & 0.07 & 27.8 & 4.2 & 1566 & 17.2 & 6460.5 & 31.5 & 11842 \\
\hline & $2500-3000$ & 9.6 & 3599.4 & 0.8 & 285.8 & 0.14 & 51.1 & 0.03 & 12.6 \\
\hline $\mathrm{S}_{3}$ & $3000-3500$ & 0.12 & $0.01<$ & 0.75 & 0.75 & $0.01<$ & 0.32 & 0 & 0 \\
\hline $\mathrm{N}$ & $<1500$ & $0.01<$ & 0.45 & 0 & 0 & $0.01<$ & 0.62 & 0.04 & 14.9 \\
\hline $\mathrm{N}_{\text {DEM }}$ & - & 63 & 23752 & 63 & 23752 & 63 & 23752 & 63 & 23752 \\
\hline
\end{tabular}

Table 3: Suitability evaluation of overlay maps of DEM with GDD in four sowing dates to freezing start day using SLA by GIS

\begin{tabular}{|c|c|c|c|c|c|c|c|c|c|}
\hline \multirow[b]{2}{*}{ Class } & \multirow[b]{2}{*}{ GDD } & \multicolumn{2}{|l|}{ Date 1} & \multicolumn{2}{|l|}{ Date 2} & \multicolumn{2}{|l|}{ Date 3} & \multicolumn{2}{|l|}{ Date 4} \\
\hline & & $\begin{array}{l}\text { Area } \\
\text { land }(\%)\end{array}$ & $\begin{array}{l}\text { Area land } \\
\left(\mathrm{Km}^{2}\right)\end{array}$ & $\begin{array}{l}\text { Area } \\
\text { land }(\%)\end{array}$ & $\begin{array}{l}\text { Area land } \\
\left(\mathrm{Km}^{2}\right)\end{array}$ & $\begin{array}{l}\text { Area } \\
\text { land }(\%)\end{array}$ & $\begin{array}{l}\text { Area land } \\
\left(\mathrm{Km}^{2}\right)\end{array}$ & $\begin{array}{l}\text { Area } \\
\text { land }(\%)\end{array}$ & $\begin{array}{l}\text { Area land } \\
\left(\mathrm{Km}^{2}\right)\end{array}$ \\
\hline $\mathrm{S}_{1}$ & $500-650$ & 20.5 & 7726 & 36.3 & 13654.7 & 0.03 & 10.1 & 0.01 & 3.1 \\
\hline $\mathrm{S}_{2}$ & $\begin{array}{l}350-500 \text { or } \\
650-800\end{array}$ & 0.09 & 3341 & 0.66 & 250.1 & 12 & 4515.7 & 0.06 & 22.9 \\
\hline $\mathrm{S}_{3}$ & $300-350$ & 15.9 & 6006.8 & $0.01<$ & 0.34 & 24.8 & 9329 & 33.4 & 1220.9 \\
\hline $\mathrm{N}$ & $<150$ or $>800$ & 0.4 & 139.4 & $0.01<$ & 0.4 & 0.13 & 50.6 & 4.4 & 1658.5 \\
\hline$* \mathrm{~N}_{\mathrm{DEM}}$ & - & 63 & 23752 & 63 & 23752 & 63 & 23752 & 63 & 23752 \\
\hline
\end{tabular}

*: Highly suitable $\left(\mathrm{S}_{1}\right)$, moderately suitable $\left(\mathrm{S}_{2}\right)$, marginally suitable $\left(\mathrm{S}_{3}\right)$, not suitable $(\mathrm{N})$ and not suitable for DEM $\left(\mathrm{N}_{\mathrm{DEM}}\right)$

Table 4: Suitability evaluation of overlay maps of DEM with climate variables in four sowing dates to using SLA by GIS

\begin{tabular}{|c|c|c|c|c|c|c|c|c|}
\hline \multirow[b]{2}{*}{ Class } & \multicolumn{2}{|l|}{ Date 1} & \multicolumn{2}{|l|}{ Date 2} & \multicolumn{2}{|l|}{ Date 3} & \multicolumn{2}{|l|}{ Date 4} \\
\hline & $\begin{array}{l}\text { Area } \\
\text { land }(\%)\end{array}$ & $\begin{array}{l}\text { Area land } \\
\left(\mathrm{Km}^{2}\right)\end{array}$ & $\begin{array}{l}\text { Area land } \\
(\%)\end{array}$ & $\begin{array}{l}\text { Area land } \\
\left(\mathrm{Km}^{2}\right)\end{array}$ & $\begin{array}{l}\text { Area land } \\
(\%)\end{array}$ & $\begin{array}{l}\text { Area land } \\
\left(\mathrm{Km}^{2}\right)\end{array}$ & $\begin{array}{l}\text { Area land } \\
(\%)\end{array}$ & $\begin{array}{l}\text { Area land } \\
\left(\mathrm{Km}^{2}\right)\end{array}$ \\
\hline $\mathrm{S}_{1}$ & 0 & 0 & 0 & 0 & 0 & 0 & 0 & 0 \\
\hline $\mathrm{S}_{2}$ & 11.2 & 4420 & 12.5 & 4709.4 & 0.4 & 147.5 & 0.06 & 23.9 \\
\hline $\mathrm{S}_{3}$ & 25.2 & 9502 & 24.3 & 9152.3 & 36.3 & 13685.7 & 32.4 & 12202.3 \\
\hline $\mathrm{N}$ & 0.49 & 182.9 & 0.12 & 43.9 & 0.19 & 72.3 & 4.5 & 1679.2 \\
\hline$* \mathrm{~N}_{\mathrm{DEM}}$ & 63 & 23752 & 63 & 23752 & 63 & 23752 & 63 & 23752 \\
\hline
\end{tabular}

*: Highly suitable $\left(\mathrm{S}_{1}\right)$, moderately suitable $\left(\mathrm{S}_{2}\right)$, marginally suitable $\left(\mathrm{S}_{3}\right)$, not suitable $(\mathrm{N})$ and not suitable for DEM $\left(\mathrm{N}_{\text {DEM }}\right)$

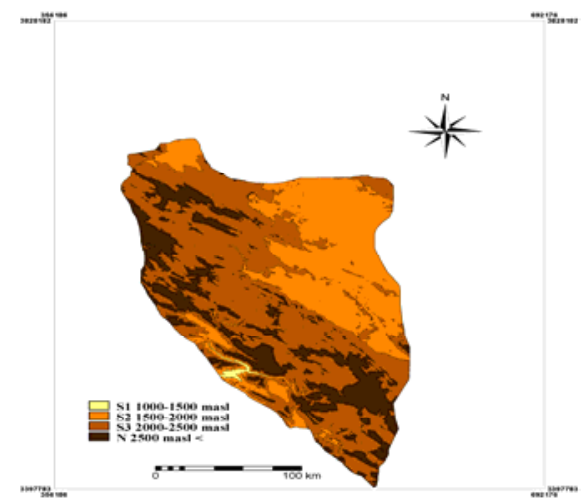

(a)

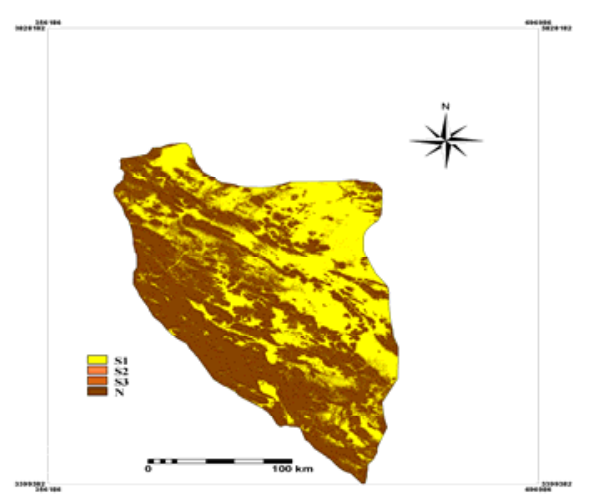

(b)

Fig. 2: Polygon map of elevation (a) and slope (b) suitability for rapeseed 

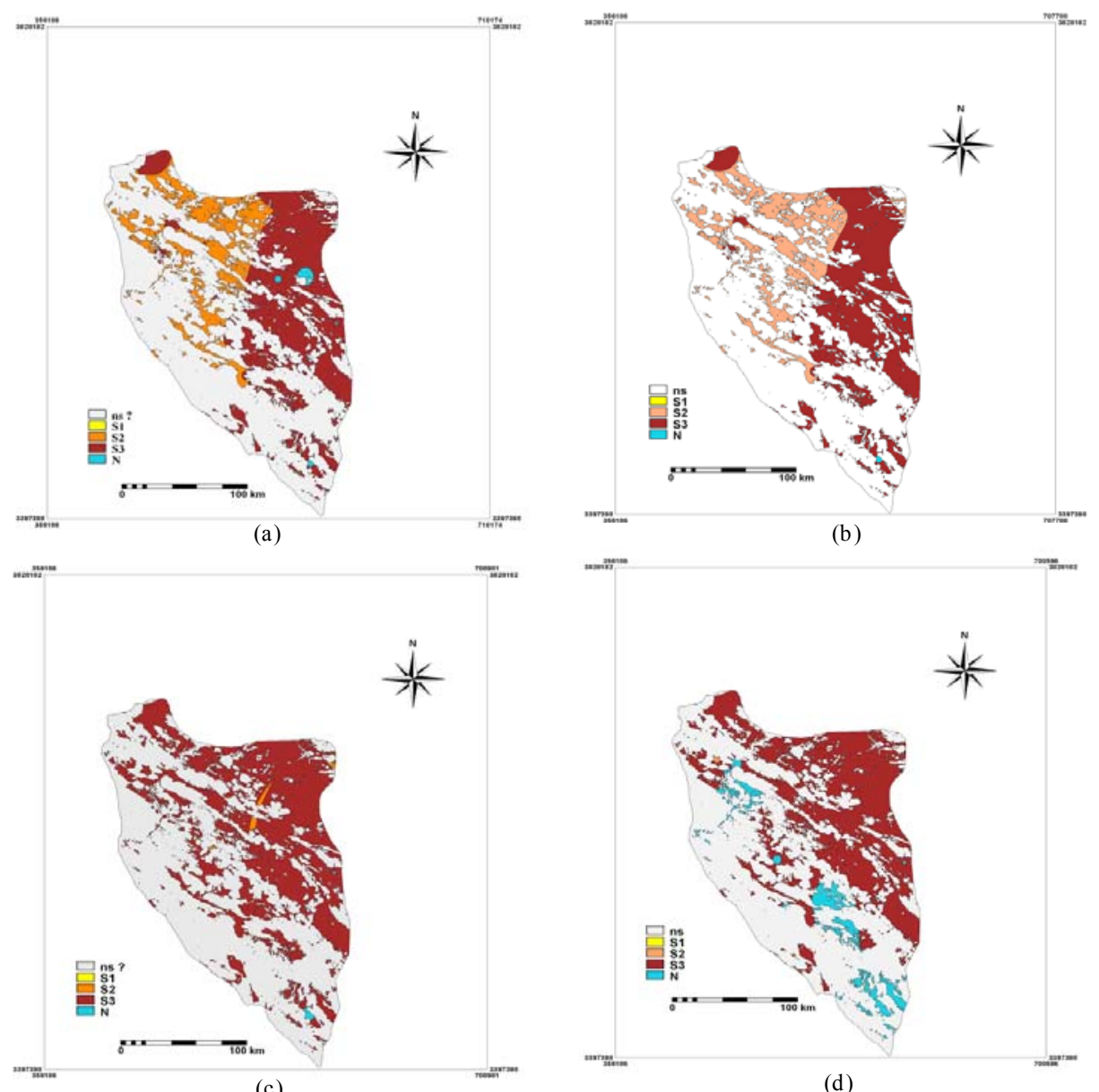

(d)

Fig. 3: Suitability evaluation of overlay maps of DEM and climate variables in four dates of sowing using SLA (a: 20 August to 5 September, b: 6 September to 20 September, c: 21 September to 5 October and d: 6 October to 20 October)

short growing season. The results of studies showed that reduced yields in late sowings were primarily related to a significantly lower number of pods per unit area and reduced seed weight ${ }^{[13]}$.

The overlay maps of DEM and climate variables for different sowing dates using SLA identified that seeding resulted in a decrease in suitable areas (Table 4 and Fig. 3).

\section{CONCLUSION}

This research confirmed that the methodology used was adequate to integrate database of climate factors with different spatial and temporal resolutions. Climate and topography environment-components proved to be useful in the identification of suitable areas for rapeseed oil crop production, within a GIS environment ${ }^{[3,10,11]}$.
This investigation is a climate evaluation that provides information at a regional level that could be used by farmers to select their crop pattern ${ }^{[7,9]}$. As well, decision-making regarding adequate crop patterns could be based not only on the information provided by this approach, but also on other aspects such as: production supports (by local and federal governments), marketing, technological level, economic evaluation, in addition to local customs, which are also highly important. The method applied is an interesting contribution for the specialists of those countries or counties with similar economy to Southwest Iran, as an alternative and reliable approach to evaluate the environment for agricultural use ${ }^{[10,11]}$. The results of present study indicated that in the most of regions especially cool conditions, delay in sowing from August to October decreased the period from sowing to rosette phase. 


\section{ACKNOWLEDGMENT}

This study received support from the vice chancellor for research at the Islamic Azad University of Shahrekord Branch (Dr. F. Fadi Fard), Meteorological Organization of Iran (Shahrekord and Isfahan Offices) and the Institute of Soil and Water of Iran.

\section{REFERENCES}

1. Ayobi, S. A and A. Jalalian, 2006. Land Evaluation (Application on Agriculture). 1st Edn. Technology University of Isfahan Press, pp: 396. ISBN: 9648476-23-3.

2. Boonyanuphap, J., D. Wattanachaiyingcharoen and S. Katsutoshi, 2004. GIS-based land suitability assessment for Musa (ABB group) plantation. J. Applied Hortic., 6: 3-10. URL: http://horticultureresearch.net/Jaruntorn.pdf.

3. Caldiz, D.O., F.J. Gaspari, A.J. Haverkort and P.C. Struik, 2001. Agro-ecological zoning and potential yield single or double cropping of potato in Argentina. Agric. Forest Meteorol., 109: 311320. DOI: 10.1016/S0168-1923(01)00231-3.

4. Calısır, S., T. Marakog Lua, H. Oguta and O. Ozturkb, 2005. Physical properties of rapeseed (Brassica napus oleifera L.). J. Food Eng., 69: 61-66. DOI: 10.1016/ j. jfoodeng.2004.07.010.

5. Ceballos-Silva, A and J. López-Blanco, 2003. Evaluating biophysical variables to identify suitable areas for oat in central Mexico: A multicriteria and GIS approach. Agric. Ecosyst. Environ. J., 95: 371-377. DOI: 10.1016/S01678809(02)00180-9.

6. Derscheid, L. A and W. L Lytle, 2002. Growing Degree Days (GDD). URL: http://agbiopubs.sdstate.edu/articles/FS522.pdf.

7. Downey, R.K., 1990. Canola: A quality brassica oilseed. p. 211-217. In: J. Janick and J.E. Simon (eds.), Advances in new crops. Timber Press, Portland, http://www.hort.purdue.edu/newcrop/ proceedings 1990/v1-211.html.

8. Food and Agriculture Organization of the United Nations (FAO), 1996. Agro-ecological Zoning Guidelines. FAO Soil Bulletin. N. 76. FAO. Rome. URL: ftp://ftp.fao.org/agl/agll/docs/misc38e.pdf.
9. Ghaffari, A.A., H.F. Cook and H.C. Lee, 2000. Integrating climate, soil and crop information: A land suitability study using GIS. In: 4th International Conference on Integrating GIS and Environmental Modeling (GIS/EM4), September 2-8, Alberta, Canada. URL: http://www.colorado.edu/research/cires/banff/pubp apers/129/.

10. Loh, K.F., M. Halid, N. Surip and S.A. Hashim, 1997. Agro-ecological zoning for south west Selangor using remote sensing and GIS. GIS development proceeding. ACRS. pp: 1-3. http://www.gisdevelopment.net/aars/acrs/1997/ps3/ ps3020.asp

11. Miralles, D.J., B.C. Ferro and G.A. Slafer, 2001. Developmental responses to sowing date in wheat, barley and rapeseed. Field Crops Res., 71: 211-223. DOI: 10.1016/S0378-4290(01)001617.

12. Myers, R. L., 1993. Determining amaranth and canola suitability in Missouri through geographic information system analysis. In. J. Janick and J.E. Simon, eds. New Crops. John Wiley and Sons, Inc, New York, pp: 102-105. http://www.hort.purdue. edu/newcrop/proceedings1993/V2-102.html.

13. Ozer, H., 2003. Sowing date and nitrogen rate effects on growth, yield and yield components of two summer rapeseed cultivars. Eur. J. Agron., 19: 453-463. DOI: 10.1016/S1161-0301(02)00136-3.

14. Sys, C., E. van Ranst, J. Debaveye, and F. Beernaart, 1993. Land Evaluation - Parts I, II and III. International Training Centre for Post-Graduate Soil Scientists (ITC), University of Ghent, Agricultural Publications No. 7, General Administration for Development Cooperation, Brussels, Belgium. http://www.opleidingen.ugent. be/studiegids/2007/EN/FACULTY/LA/COURSE/I MSERV/02000001/INDEX.HTM.

15. Taylor, A.J and C.J. Smith, 1992. Effect of sowing date and seeding rate on yield components of irrigated canola (Brassica napus L.) grown on a Red/Brown Earth in South-Eastern Australia. Aust. J. Agric. Res., 43: 1629-1641. Doi: 10.1071/AR9921629 http://www.publish.csiro. au/nid/40/paper/AR9921629.htm. 